\title{
SUBJECT INDEX - VOL 41-2013
}

16S rRNA gene

First report of genus Chroococcidiopsis (cyanobacteria) from Sri Lanka: a potential threat to human health (Magana-Arachchi D.N. \& Wanigatunge R.P.) 41:65-68 (2013)

Adulterations

Fingerprinting diesel and petrol fuels for adulteration in Sri Lanka (Kulathunga D.R. \& Mahanama K.R.R.) 41: 287-292 (2013)

Air pollution in tropics

Corticolous lichen diversity, a potential indicator for monitoring air pollution in tropics (Attanayaka A.N.P.M. \& Wijeyaratne S.C.) 41:131-140 (2013)

Annonaceae

Potent bioactivities of the endemic Annonaceae heightens its dire conservation status (Weerasinghe A., Puvenendran S., Wickramasinghe A., Karunaratne D.N., Wijesundara S. \& Karunaratne V.) 41:345-350 (2013)

Antenna radiation patterns

Optimization of the performance of patch antennas using genetic algorithms (Jayasinghe J.M.J.W. \& Uduwawala D.N.) 41:113-120 (2013)

Anthropogenic activities

A remote sensing and GIS based study in assessment of the degradation risk of the Kolonnawa marsh (Samarasinghe Y.M.P. \& Dayawansa N.D.K.) 41:327-335 (2013)

Antibacterial activity

Bioactivity evaluation of organic solvent extractions of Ganoderma lucidum: a Sri Lankan basidiomycete (Samarakoon K.W., Lee J.H., De Silva E.D., Kim E.A., Wijesundara R.L.C., Lakmal H.H.C. \& Jeon Y.J.) 41:249-257 (2013)

Antibiosis

Antixenosis and antibiosis effects of Oryza nivara accessions harbouring bph2 gene on brown planthopper [Nilaparvata lugens (Stal)] (Madurangi S.A.P., Ratnasekera D., Senanayake S.G.J.N., Samarasinghe W.L.G. \& Hemachandra P.V.) 41:147-154 (2013)

Anti-inflammatory effect

Bioactivity evaluation of organic solvent extractions of Ganoderma lucidum: a Sri Lankan basidiomycete (Samarakoon K.W., Lee J.H., De Silva E.D., Kim E.A., Wijesundara R.L.C., Lakmal H.H.C. \& Jeon Y.J.) 41:249-257 (2013)

Antioxidant activity

Potent bioactivities of the endemic Annonaceae heightens its dire conservation status (Weerasinghe A., Puvenendran S., Wickramasinghe A., Karunaratne D.N., Wijesundara S. \& Karunaratne V.) 41:345-350 (2013)

Antioxidant effect

Bioactivity evaluation of organic solvent extractions of Ganoderma lucidum: a Sri Lankan basidiomycete (Samarakoon K.W., Lee J.H., De Silva E.D., Kim E.A., Wijesundara R.L.C., Lakmal H.H.C. \& Jeon Y.J.) 41:249-257 (2013)

Antixenosis

Antixenosis and antibiosis effects of Oryza nivara accessions harbouring bph2 gene on brown planthopper [Nilaparvata lugens (Stal)] (Madurangi S.A.P., Ratnasekera D., Senanayake S.G.J.N., Samarasinghe W.L.G. \& Hemachandra P.V.) 41:147-154 (2013)

Artificial neural network

Time series regression and artificial neural network approaches for forecasting unit price of tea at Colombo auction (Hettiarachchi H.A.C.K. \& Banneheka B.M.S.G.) 41:35-40 (2013)

Ascorbic acid

Spectrophotometric and $\mathrm{pH}$-metric studies on $\mathrm{Pb}(\mathrm{II}), \mathrm{Cd}(\mathrm{II}), \mathrm{Al}(\mathrm{III})$ and $\mathrm{Cu}(\mathrm{II})$ complexes of paracetamol and ascorbic acid (Chandrathilaka A.M.D.S., Ileperuma O.A. \& Hettiarachchi C.V.) 41: 337-344 (2013)

Aspergillus niger

Aspergillus rot of ripe mangoes (Mangifera indica L.) var. Ambalavi, Willard and Karuthakolumban (Krishnapillai N. \& Wijeratnam R.S.W.) 41:69-70 (2013)

Aspergillus rot

Aspergillus rot of ripe mangoes (Mangifera indica L.) var. Ambalavi, Willard and Karuthakolumban (Krishnapillai N. \& Wijeratnam R.S.W.) 41:69-70 (2013)

Asymmetric

A novel mutual dependence measure in structure learning (Naeem M. \& Asghar S.) 41:203-208 (2013)

Auto fuels

Fingerprinting diesel and petrol fuels for adulteration in Sri Lanka (Kulathunga D.R. \& Mahanama K.R.R.) 41: 287-292 (2013)

Bandwidth

Optimization of the performance of patch antennas using genetic algorithms (Jayasinghe J.M.J.W. \& Uduwawala D.N.) 41:113-120 (2013)

Barrier properties

Natural rubber latex-clay nanocomposite: use of montmorillonite clay as an alternative for conventional $\mathrm{CaCO}_{3}\left(\mathrm{Amarasiri}_{\mathrm{A}}\right.$, $\mathrm{Ratnayake}$ U.N., De Silva U.K., Walpolage S. \& Siriwardene S.) 41: 293-302 (2013) 
Beach sand

Radioactivity levels in beach sand from the West Coast of Sri Lanka (Mahawatte P. \& Fernando K.N.R.) 41:279-285 (2013)

Bifurcation

Computer simulation of tree development with random variations and probabilistic growth of branches (Jinasena K.D.S. \& Sonnadara D.U.J.) 41:229-235 (2013)

Biochemical compounds

Use of biochemical compounds in tea germplasm characterization and its implications in tea breeding in Sri Lanka (Kottawa-Arachchi J.D., Gunasekare M.T.K., Ranatunga M.A.B., Punyasiri P.A.N. \& Jayasinghe L.) 41:309-318 (2013)

Bio-degradation

Evaluation of cellulose degrading efficiency of some fungi and bacteria and their biofilms (Gunathilake K.M.D., Ratnayake R.R., Kulasooriya S.A. \& Karunaratne D.N.) 41:155-163 (2013)

Biodiversity conservation

Potent bioactivities of the endemic Annonaceae heightens its dire conservation status (Weerasinghe A., Puvenendran S., Wickramasinghe A., Karunaratne D.N., Wijesundara S. \& Karunaratne V.) 41:345-350 (2013)

Biological data

A linear programming approach to fitting an upper quadratic boundary line to natural rubber data (Banneheka B.M.S.G., Dhanushika M.P., Wijesuriya W. \& Herath K.) 41:13-20 (2013)

Bootstrap confidence intervals

A linear programming approach to fitting an upper quadratic boundary line to natural rubber data (Banneheka B.M.S.G., Dhanushika M.P., Wijesuriya W. \& Herath K.) 41:13-20 (2013)

bph2

Antixenosis and antibiosis effects of Oryza nivara accessions harbouring bph2 gene on brown planthopper [Nilaparvata lugens (Stal)] (Madurangi S.A.P., Ratnasekera D., Senanayake S.G.J.N., Samarasinghe W.L.G. \& Hemachandra P.V.) 41:147-154 (2013)

\section{Brown planthopper}

Antixenosis and antibiosis effects of Oryza nivara accessions harbouring bph2 gene on brown planthopper [Nilaparvata lugens (Stal)] (Madurangi S.A.P., Ratnasekera D., Senanayake S.G.J.N., Samarasinghe W.L.G. \& Hemachandra P.V.) 41:147-154 (2013)

\section{Camellia sinensis}

Use of biochemical compounds in tea germplasm characterization and its implications in tea breeding in Sri Lanka (Kottawa-Arachchi J.D., Gunasekare M.T.K., Ranatunga M.A.B., Punyasiri P.A.N. \& Jayasinghe L.) 41: 309-318 (2013)

\section{Cellulose}

Evaluation of cellulose degrading efficiency of some fungi and bacteria and their biofilms (Gunathilake K.M.D., Ratnayake R.R., Kulasooriya S.A. \& Karunaratne D.N.) 41:155-163 (2013)

\section{Chaotic series}

Time series regression and artificial neural network approaches for forecasting unit price of tea at Colombo auction (Hettiarachchi H.A.C.K. \& Banneheka B.M.S.G.) 41:35-40 (2013)

\section{Chelation therapy}

Spectrophotometric and $\mathrm{pH}$-metric studies on $\mathrm{Pb}(\mathrm{II}), \mathrm{Cd}(\mathrm{II}), \mathrm{Al}(\mathrm{III})$ and $\mathrm{Cu}(\mathrm{II})$ complexes of paracetamol and ascorbic acid (Chandrathilaka A.M.D.S., Ileperuma O.A. \& Hettiarachchi C.V.) 41: 337-344 (2013)

\section{Chroococcidiopsis}

First report of genus Chroococcidiopsis (cyanobacteria) from Sri Lanka: a potential threat to human health (Magana-Arachchi D.N. \& Wanigatunge R.P.) 41:65-68 (2013)

\section{Classical approach}

Modelling electricity sales in Sri Lanka and Colombo city using different statistical methods (Pathberiya H.A. \& Dias P.) 41:41-51 (2013)

Clay

Natural rubber latex-clay nanocomposite: use of montmorillonite clay as an alternative for conventional $\mathrm{CaCO}_{3}\left(\mathrm{Amarasiri}_{\mathrm{A}}\right.$, Ratnayake U.N., De Silva U.K., Walpolage S. \& Siriwardene S.) 41: 293-302 (2013)

Cloud point

Surfactant behaviour of five carbohydrate liquid crystals (Abeyrathne A.R.N.M., Perera A.D.L.C. \& Karunaratne D.N.) 41:185-194 (2013)

Coconut

Application of un-fertilized ovary culture to identify elite mother palms of Cocos nucifera L. with regenerative potential (Vidhanaarachchi V.R.M., Fernando S.C., Perera P.I.P. \& Weerakoon L.K.) 41:29-34 (2013)

Colombo tea auction

Time series regression and artificial neural network approaches for forecasting unit price of tea at Colombo auction (Hettiarachchi H.A.C.K. \& Banneheka B.M.S.G.) 41:35-40 (2013)

\section{Concentrations}

Variation of constituent loads and concentrations with the flow in Gin river, Sri Lanka (Wickramaarachchi T.N., Ishidaira H. \& Wijayaratna T.M.N.) 41:237-247 (2013) 


\section{Constituent loads}

Variation of constituent loads and concentrations with the flow in Gin river, Sri Lanka (Wickramaarachchi T.N., Ishidaira H. \& Wijayaratna T.M.N.) 41:237-247 (2013)

\section{Core polarization}

Inelastic electron scattering from light nuclei (Sharrad F.I., Hamoudi A.K., Radhi R.A. \& Abdullah H.Y.) 41:209-217 (2013)

Corticolous lichens

Corticolous lichen diversity, a potential indicator for monitoring air pollution in tropics (Attanayaka A.N.P.M. \& Wijeyaratne S.C.) 41:131-140 (2013)

\section{Country-wide survey}

Preliminary survey of the distribution of four potentially zoonotic parasite species among primates in Sri Lanka (Huffman M.A., Nahallage C.A.D., Hasegawa H., Ekanayake S., De Silva L.D.G.G. \& Athauda I.R.K.) 41:319-326 (2013)

\section{Critical micelle concentration}

Surfactant behaviour of five carbohydrate liquid crystals (Abeyrathne A.R.N.M., Perera A.D.L.C. \& Karunaratne D.N.) 41:185-194 (2013)

Crosslink density

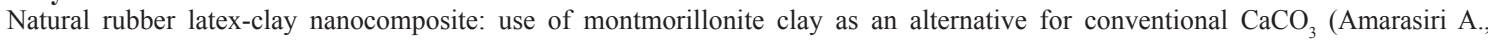
Ratnayake U.N., De Silva U.K., Walpolage S. \& Siriwardene S.) 41: 293-307 (2013)

\section{Crystal packing}

X-ray crystal structure analysis of 4,7-dioxononanoic acid (Abeysekera A.M., Padumadasa C. \& Mala S.M.V.D.) 41: $303-307$ (2013)

\section{Cyanobacteria}

First report of genus Chroococcidiopsis (cyanobacteria) from Sri Lanka: a potential threat to human health (Magana-Arachchi D.N. \& Wanigatunge R.P.) 41:65-68 (2013)

\section{Dark requirement}

Storage and germination treatments for seeds of an ornamentally important palm, Livistona rotundifolia (Lam.) Mart. (Sanjeewani B.L.G., Jayasuriya K.M.G.G., Fernando M.T.R. \& Damunupola J.W.) 41: 273-277 (2013)

\section{Degradation risk}

A remote sensing and GIS based study in assessment of the degradation risk of the Kolonnawa marsh (Samarasinghe Y.M.P. \& Dayawansa N.D.K.) 41:327-335 (2013)

\section{Dengue haemorrhagic fever}

Potential risk areas for dengue in the Jaffna Municipal Area in Northern Sri Lanka (Kannathasan S., Suthakar K., Jude P.J. \& Surendran S.N.) 41:165-168 (2013)

Dengue

Potential risk areas for dengue in the Jaffna Municipal Area in Northern Sri Lanka (Kannathasan S., Suthakar K., Jude P.J. \& Surendran S.N.) 41:165-168 (2013)

\section{Detection limits}

Radioactivity levels in beach sand from the West Coast of Sri Lanka (Mahawatte P. \& Fernando K.N.R.) 41:279-285 (2013)

Differential hybridization

Identification of differentially-expressed genes in response to salt stress in the salt-tolerant Sri Lankan rice variety At354 (Zahra A.R.F., De Costa D.M. \& De Costa W.A.J.M.) 41:93-112 (2013)

Dioxocarboxylic acids

X-ray crystal structure analysis of 4,7-dioxononanoic acid (Abeysekera A.M., Padumadasa C. \& Mala S.M.V.D.) 41: $303-307$ (2013)

Dipole-dipole interactions

X-ray crystal structure analysis of 4,7-dioxononanoic acid (Abeysekera A.M., Padumadasa C. \& Mala S.M.V.D.) 41: $303-307$ (2013)

Domestic

Gastrointestinal parasites of dogs in Hantana area in the Kandy District (Perera P.K., Rajapakse R.P.V.J. \& Rajakaruna R.S.) 41:81-91 (2013)

Dye sensitized

Conductivity behaviour in novel quasi-solid-state electrolyte based on polyacrylonitrile and tetrahexylammonium iodide intended for dye sensitized solar cells (Bandara T.M.W.J., Svensson T., Dissanayake M.A.K.L., Furlani M., Jayasundara W.J.M.J.S.R., Fernando P.S.L., Albinsson I. \& Mellander B.E.) 41:175-184 (2013)

E. coli

Preliminary survey of the distribution of four potentially zoonotic parasite species among primates in Sri Lanka (Huffman M.A., Nahallage C.A.D., Hasegawa H., Ekanayake S., De Silva L.D.G.G. \& Athauda I.R.K.) 41:319-326 (2013)

\section{E. histolytica/dispar}

Preliminary survey of the distribution of four potentially zoonotic parasite species among primates in Sri Lanka (Huffman M.A., Nahallage C.A.D., Hasegawa H., Ekanayake S., De Silva L.D.G.G. \& Athauda I.R.K.) 41:319-326 (2013)

Electron scattering 
Embryo growth

Identifying dormancy class and storage behaviour of champak (Magnolia champaca) seeds, an important tropical timber tree (Fernando M.T.R., Jayasuriya K.M.G.G., Walck J.L. \& Wijetunga A.S.T.B.) 41:141-146 (2013)

Endemic species

Potent bioactivities of the endemic Annonaceae heightens its dire conservation status (Weerasinghe A., Puvenendran S., Wickramasinghe A., Karunaratne D.N., Wijesundara S. \& Karunaratne V.) 41:345-350 (2013)

Exfoliation

Natural rubber latex-clay nanocomposite: use of montmorillonite clay as an alternative for conventional $\mathrm{CaCO}_{3}\left(\mathrm{Amarasiri}_{\mathrm{A}}\right.$., Ratnayake U.N., De Silva U.K., Walpolage S. \& Siriwardene S.) 41: 293-302 (2013)

Explant

In vitro propagation of Pterocarpus santalinus L. (Red Sandalwood) through tissue culture (Warakagoda P.S. \& Subasinghe S.) 41:53-63 (2013)

Exponential smoothing approach

Modelling electricity sales in Sri Lanka and Colombo city using different statistical methods (Pathberiya H.A. \& Dias P.) 41:41-51 (2013)

Forecasting

Modelling electricity sales in Sri Lanka and Colombo city using different statistical methods (Pathberiya H.A. \& Dias P.) 41:41-51 (2013)

Forecasting prices

Time series regression and artificial neural network approaches for forecasting unit price of tea at Colombo auction (Hettiarachchi H.A.C.K. \& Banneheka B.M.S.G.) 41:35-40 (2013)

\section{Fungal-bacterial biofilms}

Evaluation of cellulose degrading efficiency of some fungi and bacteria and their biofilms (Gunathilake K.M.D., Ratnayake R.R., Kulasooriya S.A. \& Karunaratne D.N.) 41:155-163 (2013)

Gamma ray spectrometry

Radioactivity levels in beach sand from the West Coast of Sri Lanka (Mahawatte P. \& Fernando K.N.R.) 41:279-285 (2013)

\section{Ganoderma lucidum}

Bioactivity evaluation of organic solvent extractions of Ganoderma lucidum: a Sri Lankan basidiomycete (Samarakoon K.W., Lee J.H., De Silva E.D., Kim E.A., Wijesundara R.L.C., Lakmal H.H.C. \& Jeon Y.J.) 41:249-257 (2013)

\section{Gel polymer electrolyte}

Conductivity behaviour in novel quasi-solid-state electrolyte based on polyacrylonitrile and tetrahexylammonium iodide intended for dye sensitized solar cells (Bandara T.M.W.J., Svensson T., Dissanayake M.A.K.L., Furlani M., Jayasundara W.J.M.J.S.R., Fernando P.S.L., Albinsson I. \& Mellander B.E.) 41:175-184 (2013)

\section{Gene expression}

Identification of differentially-expressed genes in response to salt stress in the salt-tolerant Sri Lankan rice variety At354 (Zahra A.R.F., De Costa D.M. \& De Costa W.A.J.M.) 41:93-112 (2013)

\section{Genetic algorithm optimization}

Optimization of the performance of patch antennas using genetic algorithms (Jayasinghe J.M.J.W. \& Uduwawala D.N.) 41:113-120 (2013)

Geographic information systems

Potential risk areas for dengue in the Jaffna Municipal Area in Northern Sri Lanka (Kannathasan S., Suthakar K., Jude P.J. \& Surendran S.N.) 41:165-168 (2013)

\section{Germplasm characterization}

Use of biochemical compounds in tea germplasm characterization and its implications in tea breeding in Sri Lanka (Kottawa-Arachchi J.D., Gunasekare M.T.K., Ranatunga M.A.B., Punyasiri P.A.N. \& Jayasinghe L.) 41: 309-318 (2013)

Glycolipids

Surfactant behaviour of five carbohydrate liquid crystals (Abeyrathne A.R.N.M., Perera A.D.L.C. \& Karunaratne D.N.) 41:185-194 (2013)

Graded bandgap

Effective harvesting of photons for improvement of solar energy conversion by graded bandgap multilayer solar cells (Dharmadasa I.M., Kalyanaratne N.D.P.S.R. \& Dharmadasa R.) 41:73-80 (2013)

\section{Groundwater pollution}

Fate of urea fertilizers in sandy aquifers: laboratory and field case study from Kalpitiya, Sri Lanka (Jayasingha P., Pitawala A. \& Dharmagunawardhana H.A.) 41:121-129 (2013)

\section{Groundwater}

Seasonal variation of water table and groundwater quality of the karst aquifer of the Jaffna Peninsula-Sri Lanka (Joshua W.D., Thushyanthy M. \& Nanthagoban N.) 41:3-12 (2013)

Helminths

Gastrointestinal and blood parasites of a free grazing flock of sheep in Kaithady farm in the Jaffna District (Kandasamy G., Rajapakse R.P.V.J. \& Rajakaruna R.S.) 41:195-201 (2013)

\section{Helminths}

Gastrointestinal parasites of dogs in Hantana area in the Kandy District (Perera P.K., Rajapakse R.P.V.J. \& Rajakaruna R.S.) 41:81-91 (2013) 
High radiation background area

Radioactivity levels in beach sand from the West Coast of Sri Lanka (Mahawatte P. \& Fernando K.N.R.) 41:279-285 (2013)

Holocene aridity

Chronological framework of Asian Southwest Monsoon events and variations over the past 24,000 years in Sri Lanka and regional correlations (Premathilake R. \& Gunatilaka A.) 41:219-228 (2013)

\section{Hookworm}

Preliminary survey of the distribution of four potentially zoonotic parasite species among primates in Sri Lanka (Huffman M.A., Nahallage C.A.D., Hasegawa H., Ekanayake S., De Silva L.D.G.G. \& Athauda I.R.K.) 41:319-326 (2013)

\section{Hydrogen bonding}

X-ray crystal structure analysis of 4,7-dioxononanoic acid (Abeysekera A.M., Padumadasa C. \& Mala S.M.V.D.) 41: 303-307 (2013)

Hydrophilic lipophilic balance

Surfactant behaviour of five carbohydrate liquid crystals (Abeyrathne A.R.N.M., Perera A.D.L.C. \& Karunaratne D.N.) 41:185-14 (2013)

In vitro

In vitro propagation of Pterocarpus santalinus L. (Red Sandalwood) through tissue culture (Warakagoda P.S. \& Subasinghe S.) 41:53-63 (2013)

In vivo

In vitro propagation of Pterocarpus santalinus L. (Red Sandalwood) through tissue culture (Warakagoda P.S. \& Subasinghe S.) 41:53-63 (2013)

Index of atmospheric purity (IAP)

Corticolous lichen diversity, a potential indicator for monitoring air pollution in tropics (Attanayaka A.N.P.M. \& Wijeyaratne S.C.) 41:131-140 (2013)

Information theory

A novel mutual dependence measure in structure learning (Naeem M. \& Asghar S.) 41:203-208 (2013)

\section{Intermediate storage}

Identifying dormancy class and storage behaviour of champak (Magnolia champaca) seeds, an important tropical timber tree (Fernando M.T.R., Jayasuriya K.M.G.G., Walck J.L. \& Wijetunga A.S.T.B.) 41:141-146 (2013)

Ionic conductivity

Conductivity behaviour in novel quasi-solid-state electrolyte based on polyacrylonitrile and tetrahexylammonium iodide intended for dye sensitized solar cells (Bandara T.M.W.J., Svensson T., Dissanayake M.A.K.L., Furlani M., Jayasundara W.J.M.J.S.R., Fernando P.S.L., Albinsson I. \& Mellander B.E.) 41:175-184 (2013)

IR spectroscopy

X-ray crystal structure analysis of 4,7-dioxononanoic acid (Abeysekera A.M., Padumadasa C. \& Mala S.M.V.D.) 41: 303-307 (2013)

Jaffna Local

Gastrointestinal and blood parasites of a free grazing flock of sheep in Kaithady farm in the Jaffna District (Kandasamy G., Rajapakse R.P.V.J. \& Rajakaruna R.S.) 41:195-201 (2013)

Jaffna Municipal Area

Potential risk areas for dengue in the Jaffna Municipal Area in Northern Sri Lanka (Kannathasan S., Suthakar K., Jude P.J. \& Surendran S.N.) 41:165-168 (2013)

Kalpitiya

Fate of urea fertilizers in sandy aquifers: laboratory and field case study from Kalpitiya, Sri Lanka (Jayasingha P., Pitawala A. \& Dharmagunawardhana H.A.) 41:121-129 (2013)

Kandy traffic

Improvement of pedestrian safety and traffic flow regulation at the railway junction, Kandy (Gopallawa D.C. \& Weerasekera K.S.) 41:259-270 (2013)

Kerosene

Fingerprinting diesel and petrol fuels for adulteration in Sri Lanka (Kulathunga D.R. \& Mahanama K.R.R.) 41: 287-292 (2013)

Kolonnawa marsh

A remote sensing and GIS based study in assessment of the degradation risk of the Kolonnawa marsh (Samarasinghe Y.M.P. \& Dayawansa N.D.K.) 41:327-335 (2013)

Lambs

Gastrointestinal and blood parasites of a free grazing flock of sheep in Kaithady farm in the Jaffna District (Kandasamy G., Rajapakse R.P.V.J. \& Rajakaruna R.S.) 41:195-201 (2013)

Light nuclei

Inelastic electron scattering from light nuclei (Sharrad F.I., Hamoudi A.K., Radhi R.A. \& Abdullah H.Y.) 41:209-217 (2013)

Limestone aquifer

Seasonal variation of water table and groundwater quality of the karst aquifer of the Jaffna Peninsula-Sri Lanka (Joshua W.D., Thushyanthy M. \& Nanthagoban N.) 41:3-12 (2013)

Limiting response

A linear programming approach to fitting an upper quadratic boundary line to natural rubber data (Banneheka B.M.S.G., Dhanushika M.P., Wijesuriya W. \& Herath K.) 41:13-20 (2013) 


\section{Linear programming}

A linear programming approach to fitting an upper quadratic boundary line to natural rubber data (Banneheka B.M.S.G., Dhanushika M.P., Wijesuriya W. \& Herath K.) 41:13-20 (2013)

\section{Livistona rotundifolia}

Storage and germination treatments for seeds of an ornamentally important palm, Livistona rotundifolia (Lam.) Mart. (Sanjeewani B.L.G., Jayasuriya K.M.G.G., Fernando M.T.R. \& Damunupola J.W.) 41: 273-277 (2013)

\section{Load-discharge rating curve}

Variation of constituent loads and concentrations with the flow in Gin river, Sri Lanka (Wickramaarachchi T.N., Ishidaira H. \& Wijayaratna T.M.N.) 41:237-247 (2013)

L-systems

Computer simulation of tree development with random variations and probabilistic growth of branches (Jinasena K.D.S. \& Sonnadara D.U.J.) 41:229-235 (2013)

\section{Magnolia champaca}

Identifying dormancy class and storage behaviour of champak (Magnolia champaca) seeds, an important tropical timber tree (Fernando M.T.R., Jayasuriya K.M.G.G., Walck J.L. \& Wijetunga A.S.T.B.) 41:141-146 (2013)

Mangoes

Aspergillus rot of ripe mangoes (Mangifera indica L.) var. Ambalavi, Willard and Karuthakolumban (Krishnapillai N. \& Wijeratnam R.S.W.) 41:69-70 (2013)

\section{Mean temperature}

Reconstruction of missing monthly temperature observations in Jaffna, Sri Lanka (Thevakaran A. \& Sonnadara D.U.J.) 41:21-28 (2013)

\section{Michelia champaca}

Identifying dormancy class and storage behaviour of champak (Magnolia champaca) seeds, an important tropical timber tree (Fernando M.T.R., Jayasuriya K.M.G.G., Walck J.L. \& Wijetunga A.S.T.B.) 41:141-146 (2013)

Millennial cycles

Chronological framework of Asian Southwest Monsoon events and variations over the past 24,000 years in Sri Lanka and regional correlations (Premathilake R. \& Gunatilaka A.) 41:219-228 (2013)

Missing data

Reconstruction of missing monthly temperature observations in Jaffna, Sri Lanka (Thevakaran A. \& Sonnadara D.U.J.) 41:21-28 (2013)

\section{Mixed ligand complexes}

Spectrophotometric and $\mathrm{pH}$-metric studies on $\mathrm{Pb}(\mathrm{II}), \mathrm{Cd}(\mathrm{II}), \mathrm{Al}(\mathrm{III})$ and $\mathrm{Cu}(\mathrm{II})$ complexes of paracetamol and ascorbic acid (Chandrathilaka A.M.D.S., Ileperuma O.A. \& Hettiarachchi C.V.) 41: 337-344 (2013)

\section{Mixed-cultures}

Evaluation of cellulose degrading efficiency of some fungi and bacteria and their biofilms (Gunathilake K.M.D., Ratnayake R.R., Kulasooriya S.A. \& Karunaratne D.N.) 41:155-163 (2013)

\section{Moisture content}

Identifying dormancy class and storage behaviour of champak (Magnolia champaca) seeds, an important tropical timber tree (Fernando M.T.R., Jayasuriya K.M.G.G., Walck J.L. \& Wijetunga A.S.T.B.) 41:141-146 (2013)

\section{Molar conductivity}

Conductivity behaviour in novel quasi-solid-state electrolyte based on polyacrylonitrile and tetrahexylammonium iodide intended for dye sensitized solar cells (Bandara T.M.W.J., Svensson T., Dissanayake M.A.K.L., Furlani M., Jayasundara W.J.M.J.S.R., Fernando P.S.L., Albinsson I. \& Mellander B.E.) 41:175-184 (2013)

\section{Monocultures}

Evaluation of cellulose degrading efficiency of some fungi and bacteria and their biofilms (Gunathilake K.M.D., Ratnayake R.R., Kulasooriya S.A. \& Karunaratne D.N.) 41:155-163 (2013)

\section{Morphophysiological dormancy}

Identifying dormancy class and storage behaviour of champak (Magnolia champaca) seeds, an important tropical timber tree (Fernando M.T.R., Jayasuriya K.M.G.G., Walck J.L. \& Wijetunga A.S.T.B.) 41:141-146 (2013)

\section{Mosquito larvicidal activity}

Potent bioactivities of the endemic Annonaceae heightens its dire conservation status (Weerasinghe A., Puvenendran S., Wickramasinghe A., Karunaratne D.N., Wijesundara S. \& Karunaratne V.) 41:345-350 (2013)

\section{Mother palm selection}

Application of un-fertilized ovary culture to identify elite mother palms of Cocos nucifera $\mathrm{L}$. with regenerative potential(Vidhanaarachchi V.R.M., Fernando S.C., Perera P.I.P. \& Weerakoon L.K.) 41:29-34 (2013)

\section{Mutual dependence}

A novel mutual dependence measure in structure learning (Naeem M. \& Asghar S.) 41:203-208 (2013)

\section{Nanocomposites}

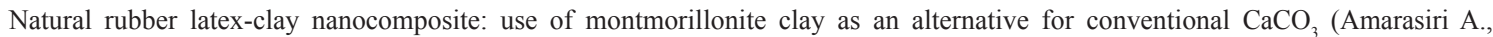
Ratnayake U.N., De Silva U.K., Walpolage S. \& Siriwardene S.) 41: 293-302 (2013) 


\section{Natural rubber latex}

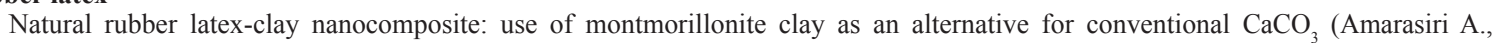
Ratnayake U.N., De Silva U.K., Walpolage S. \& Siriwardene S.) 41: 293-302 (2013)

\section{Next generation solar cells}

Effective harvesting of photons for improvement of solar energy conversion by graded bandgap multilayer solar cells (Dharmadasa I.M., Kalyanaratne N.D.P.S.R. \& Dharmadasa R.) 41:73-80 (2013)

Nitrate

Fate of urea fertilizers in sandy aquifers: laboratory and field case study from Kalpitiya, Sri Lanka (Jayasingha P., Pitawala A. \& Dharmagunawardhana H.A.) 41:121-129 (2013)

Non-deep physiological dormancy

Storage and germination treatments for seeds of an ornamentally important palm, Livistona rotundifolia (Lam.) Mart. (Sanjeewani B.L.G., Jayasuriya K.M.G.G., Fernando M.T.R. \& Damunupola J.W.) 41: 273-277 (2013)

\section{On-line HPLC-ABTS}

Bioactivity evaluation of organic solvent extractions of Ganoderma lucidum: a Sri Lankan basidiomycete (Samarakoon K.W., Lee J.H., De Silva E.D., Kim E.A., Wijesundara R.L.C., Lakmal H.H.C. \& Jeon Y.J.) 41:249-257 (2013)

Oryza nivara

Antixenosis and antibiosis effects of Oryza nivara accessions harbouring bph2 gene on brown planthopper [Nilaparvata lugens (Stal)] (Madurangi S.A.P., Ratnasekera D., Senanayake S.G.J.N., Samarasinghe W.L.G. \& Hemachandra P.V.) 41:147-154 (2013)

\section{Oryza sativa}

Identification of differentially-expressed genes in response to salt stress in the salt-tolerant Sri Lankan rice variety At354 (Zahra A.R.F., De Costa D.M. \& De Costa W.A.J.M.) 41:93-112 (2013)

PAHs

Fingerprinting diesel and petrol fuels for adulteration in Sri Lanka (Kulathunga D.R. \& Mahanama K.R.R.) 41: 287-292 (2013)

Palaeomonsoons

Chronological framework of Asian Southwest Monsoon events and variations over the past 24,000 years in Sri Lanka and regional correlations (Premathilake R. \& Gunatilaka A.) 41:219-228 (2013)

Paracetamol

Spectrophotometric and $\mathrm{pH}$-metric studies on $\mathrm{Pb}(\mathrm{II}), \mathrm{Cd}(\mathrm{II}), \mathrm{Al}(\mathrm{III})$ and $\mathrm{Cu}(\mathrm{II})$ complexes of paracetamol and ascorbic acid (Chandrathilaka A.M.D.S., Ileperuma O.A. \& Hettiarachchi C.V.) 41: 337-344 (2013)

Patch antennas

Optimization of the performance of patch antennas using genetic algorithms (Jayasinghe J.M.J.W. \& Uduwawala D.N.) 41:113-120 (2013)

Photon harvesting

Effective harvesting of photons for improvement of solar energy conversion by graded bandgap multilayer solar cells (Dharmadasa I.M., Kalyanaratne N.D.P.S.R. \& Dharmadasa R.) 41:73-80 (2013)

Plant modeling

Computer simulation of tree development with random variations and probabilistic growth of branches (Jinasena K.D.S. \& Sonnadara D.U.J.) 41:229-235 (2013)

Polyacrylonitrile

Conductivity behaviour in novel quasi-solid-state electrolyte based on polyacrylonitrile and tetrahexylammonium iodide intended for dye sensitized solar cells (Bandara T.M.W.J., Svensson T., Dissanayake M.A.K.L., Furlani M., Jayasundara W.J.M.J.S.R., Fernando P.S.L., Albinsson I. \& Mellander B.E.) 41:175-184 (2013)

Proliferation

In vitro propagation of Pterocarpus santalinus L. (Red Sandalwood) through tissue culture (Warakagoda P.S. \& Subasinghe S.) $41: 53-63$ (2013)

\section{Protozoans}

Gastrointestinal and blood parasites of a free grazing flock of sheep in Kaithady farm in the Jaffna District (Kandasamy G., Rajapakse R.P.V.J. \& Rajakaruna R.S.) 41:195-201 (2013)

Protozoans

Gastrointestinal parasites of dogs in Hantana area in the Kandy District (Perera P.K., Rajapakse R.P.V.J. \& Rajakaruna R.S.) 41:81-91 (2013)

Pterocarpus santalinus L.

In vitro propagation of Pterocarpus santalinus L. (Red Sandalwood) through tissue culture (Warakagoda P.S. \& Subasinghe S.) 41:53-63 (2013)

Railway junction

Improvement of pedestrian safety and traffic flow regulation at the railway junction, Kandy (Gopallawa D.C. \& Weerasekera K.S.) 41:259-270 (2013)

\section{Rainforest diversity}

Chronological framework of Asian Southwest Monsoon events and variations over the past 24,000 years in Sri Lanka and regional correlations (Premathilake R. \& Gunatilaka A.) 41:219-228 (2013) 


\section{Recalcitrance}

Storage and germination treatments for seeds of an ornamentally important palm, Livistona rotundifolia (Lam.) Mart. (Sanjeewani B.L.G., Jayasuriya K.M.G.G., Fernando M.T.R. \& Damunupola J.W.) 41: 273-277 (2013)

\section{Regional chronology}

Chronological framework of Asian Southwest Monsoon events and variations over the past 24,000 years in Sri Lanka and regional correlations (Premathilake R. \& Gunatilaka A.) 41:219-228 (2013)

Regression models

Variation of constituent loads and concentrations with the flow in Gin river, Sri Lanka (Wickramaarachchi T.N., Ishidaira H. \& Wijayaratna T.M.N.) 41:237-247 (2013)

Risk map

Potential risk areas for dengue in the Jaffna Municipal Area in Northern Sri Lanka (Kannathasan S., Suthakar K., Jude P.J. \& Surendran S.N.) 41:165-168 (2013)

\section{Risk mapping}

A remote sensing and GIS based study in assessment of the degradation risk of the Kolonnawa marsh (Samarasinghe Y.M.P. \& Dayawansa N.D.K.) 41:327-335 (2013)

Salt stress

Identification of differentially-expressed genes in response to salt stress in the salt-tolerant Sri Lankan rice variety At354 (Zahra A.R.F., De Costa D.M. \& De Costa W.A.J.M.) 41:93-112 (2013)

\section{Salt tolerant genes}

Identification of differentially-expressed genes in response to salt stress in the salt-tolerant Sri Lankan rice variety At354 (Zahra A.R.F., De Costa D.M. \& De Costa W.A.J.M.) 41:93-112 (2013)

Scintillation spectrometry

Radioactivity levels in beach sand from the West Coast of Sri Lanka (Mahawatte P. \& Fernando K.N.R.) 41:279-285 (2013)

Semi-domestic dogs

Gastrointestinal parasites of dogs in Hantana area in the Kandy District (Perera P.K., Rajapakse R.P.V.J. \& Rajakaruna R.S.) 41:81-91 (2013)

Sheep

Gastrointestinal and blood parasites of a free grazing flock of sheep in Kaithady farm in the Jaffna District (Kandasamy G., Rajapakse R.P.V.J. \& Rajakaruna R.S.) 41:195-201 (2013)

Short range

Inelastic electron scattering from light nuclei (Sharrad F.I., Hamoudi A.K., Radhi R.A. \& Abdullah H.Y.) 41:209-217 (2013)

Simulation

Computer simulation of tree development with random variations and probabilistic growth of branches (Jinasena K.D.S. \& Sonnadara D.U.J.) 41:229-235 (2013)

Solar cell

Conductivity behaviour in novel quasi-solid-state electrolyte based on polyacrylonitrile and tetrahexylammonium iodide intended for dye sensitized solar cells (Bandara T.M.W.J., Svensson T., Dissanayake M.A.K.L., Furlani M., Jayasundara W.J.M.J.S.R., Fernando P.S.L., Albinsson I. \& Mellander B.E.) 41:175-184 (2013)

Solar cells

Effective harvesting of photons for improvement of solar energy conversion by graded bandgap multilayer solar cells (Dharmadasa I.M., Kalyanaratne N.D.P.S.R. \& Dharmadasa R.) 41:73-80 (2013)

Somatic embryogenesis

Application of un-fertilized ovary culture to identify elite mother palms of Cocos nucifera L. with regenerative potential(Vidhanaarachchi V.R.M., Fernando S.C., Perera P.I.P. \& Weerakoon L.K.) 41:29-34 (2013)

Sri Lanka

Chronological framework of Asian Southwest Monsoon events and variations over the past 24,000 years in Sri Lanka and regional correlations (Premathilake R. \&. Gunatilaka A.) 41:219-228 (2013)

Sri Lanka

Radioactivity levels in beach sand from the West Coast of Sri Lanka (Mahawatte P. \& Fernando K.N.R.) 41:279-285 (2013)

Stability constants

Spectrophotometric and $\mathrm{pH}$-metric studies on $\mathrm{Pb}(\mathrm{II}), \mathrm{Cd}(\mathrm{II}), \mathrm{Al}(\mathrm{III})$ and $\mathrm{Cu}(\mathrm{II})$ complexes of paracetamol and ascorbic acid (Chandrathilaka A.M.D.S., Ileperuma O.A. \& Hettiarachchi C.V.) 41: 337-344 (2013)

\section{Standard departure}

Reconstruction of missing monthly temperature observations in Jaffna, Sri Lanka (Thevakaran A. \& Sonnadara D.U.J.) 41:21-28 (2013)

Stochastic approach

Modelling electricity sales in Sri Lanka and Colombo city using different statistical methods (Pathberiya H.A. \& Dias P.) 41:41-51 (2013)

Stochastic processes

Computer simulation of tree development with random variations and probabilistic growth of branches (Jinasena K.D.S. \& Sonnadara D.U.J.) 41:229-235 (2013) 
Stream flow

Variation of constituent loads and concentrations with the flow in Gin river, Sri Lanka (Wickramaarachchi T.N., Ishidaira H. \& Wijayaratna T.M.N.) 41:237-247 (2013)

Structure learning

A novel mutual dependence measure in structure learning (Naeem M. \& Asghar S.) 41:203-208 (2013)

Surface sterilization

In vitro propagation of Pterocarpus santalinus L. (Red Sandalwood) through tissue culture (Warakagoda P.S. \& Subasinghe S.) 41:53-63 (2013)

Surfactants

Surfactant behaviour of five carbohydrate liquid crystals (Abeyrathne A.R.N.M., Perera A.D.L.C. \& Karunaratne D.N.) 41:185-194 (2013)

\section{Synchronous fluorescence}

Fingerprinting diesel and petrol fuels for adulteration in Sri Lanka (Kulathunga D.R. \& Mahanama K.R.R.) 41: 287-292 (2013)

Tea

Use of biochemical compounds in tea germplasm characterization and its implications in tea breeding in Sri Lanka (Kottawa-Arachchi J.D., Gunasekare M.T.K., Ranatunga M.A.B., Punyasiri P.A.N. \& Jayasinghe L.) 41: 309-318 (2013)

\section{Temporal changes}

A remote sensing and GIS based study in assessment of the degradation risk of the Kolonnawa marsh (Samarasinghe Y.M.P. \& Dayawansa N.D.K.) 41:327-335 (2013)

\section{Terrestrial fungi}

Bioactivity evaluation of organic solvent extractions of Ganoderma lucidum: a Sri Lankan basidiomycete (Samarakoon K.W., Lee J.H., De Silva E.D., Kim E.A., Wijesundara R.LC., Lakmal H.H.C. \& Jeon Y.J.) 41:249-257 (2013)

Time series

Modelling electricity sales in Sri Lanka and Colombo city using different statistical methods (Pathberiya H.A. \& Dias P.) 41:41-51 (2013)

Time series regression

Time series regression and artificial neural network approaches for forecasting unit price of tea at Colombo auction (Hettiarachchi H.A.C.K. \& Banneheka B.M.S.G.) 41:35-40 (2013)

Toxic metals

Spectrophotometric and $\mathrm{pH}$-metric studies on $\mathrm{Pb}(\mathrm{II}), \mathrm{Cd}(\mathrm{II}), \mathrm{Al}(\mathrm{III})$ and $\mathrm{Cu}(\mathrm{II})$ complexes of paracetamol and ascorbic acid (Chandrathilaka A.M.D.S., Ileperuma O.A. \& Hettiarachchi C.V.) 41: 337-344 (2013)

Traffic signal design

Improvement of pedestrian safety and traffic flow regulation at the railway junction, Kandy (Gopallawa D.C. \& Weerasekera K.S.) 41:259-270 (2013)

Trichuris sp.

Preliminary survey of the distribution of four potentially zoonotic parasite species among primates in Sri Lanka (Huffman M.A., Nahallage C.A.D., Hasegawa H., Ekanayake S., De Silva L.D.G.G. \& Athauda I.R.K.) 41:319-326 (2013)

Underground pedestrian crossings

Improvement of pedestrian safety and traffic flow regulation at the railway junction, Kandy (Gopallawa D.C. \& Weerasekera K.S.) 41:259-270 (2013)

Un-fertilized ovary culture

Application of un-fertilized ovary culture to identify elite mother palms of Cocos nucifera L. with regenerative potential(Vidhanaarachchi V.R.M., Fernando S.C., Perera P.I.P. \& Weerakoon L.K.) 41:29-34 (2013)

Urea fertilizer

Fate of urea fertilizers in sandy aquifers: laboratory and field case study from Kalpitiya, Sri Lanka (Jayasingha P., Pitawala A. \& Dharmagunawardhana H.A.) 41:121-129 (2013)

Water quality

Seasonal variation of water table and groundwater quality of the karst aquifer of the Jaffna Peninsula-Sri Lanka (Joshua W.D., Thushyanthy M. \& Nanthagoban N.) 41:3-12 (2013)

Water table

Seasonal variation of water table and groundwater quality of the karst aquifer of the Jaffna Peninsula-Sri Lanka (Joshua W.D., Thushyanthy M. \& Nanthagoban N.) 41:3-12 (2013)

\section{Weather stations}

Reconstruction of missing monthly temperature observations in Jaffna, Sri Lanka (Thevakaran A. \& Sonnadara D.U.J.) 41:21-28 (2013)

X-ray crystallography

X-ray crystal structure analysis of 4,7-dioxononanoic acid (Abeysekera A.M., Padumadasa C. \& Mala S.M.V.D.) 41: $303-307$ (2013)

Zoonoses

Gastrointestinal parasites of dogs in Hantana area in the Kandy District (Perera P.K., Rajapakse R.P.V.J. \& Rajakaruna R.S.) 41:81-91 (2013)

Zoonoses

Preliminary survey of the distribution of four potentially zoonotic parasite species among primates in Sri Lanka (Huffman M.A., Nahallage C.A.D., Hasegawa H., Ekanayake S., De Silva L.D.G.G. \& Athauda I.R.K.) 41:319-326 (2013) 